\title{
Knowledge Sharing Sebagai Mediasi Antara Employee Engagement Terhadap Kinerja Pengemudi Gojek Di Yogyakarta
}

\author{
Hamzah Gunawan ${ }^{(1)}$ Andri Wisnu Wardana ${ }^{(2)}$ \\ ${ }^{1,2}$, Universitas Mercu Buana Yogyakarta \\ ${ }^{(1)}$ hamzah@mercubuana-yogya.ac.id \\ (2) andri@mercubuana-yogya.ac.id
}

Tersedia Online di

http://www.jurnal.unublitar.ac.id/ index.php/briliant

\section{Sejarah Artikel}

Diterima pada 07 Oktober 2018

Disetuji pada 06 November 2018

Dipublikasikan pada 20

November 2018 Hal. 411-424

Kata Kunci:

Knowledge sharing, Employee engagement, Kinerja

DOI:

http://dx.doi.org/10.28926/briliant .v3i3.229
Abstrak: Banyak sekali perusahaan baru bermunculan dengan berbasis teknologi digital. Perusahaan ini menawarkan layanan dengan menggunakan aplikasi baru untuk konsumen maupun karyawan. Gojek merupakan salah satu perusahaan besar berbasis teknologi digital yang sedang banyak digunakan oleh masyarakat Indonesia. Perkembangan teknologi yang sangat cepat menuntut karyawan selalu belajar menggunakannya dan melakukan knowledge sharing. Gojek selalu mengembangkan banyak layanan baru untuk membidik peluang bisnis baru. Penelitian ini meneliti tentang pengaruh langsung employee engagement terhadap knowledge sharing dan kinerja, maupun peran knowledge sharing sebagai mediasi antara employee engagement terhadap kinerja pengemudi Gojek di Yogyakarta. Populasi dalam penelitian ini adalah seluruh pengemudi Gojek di Yogyakarta. Teknik sampel yang digunakan yaitu purposive sampling dengan jumlah sampel sebanyak 200 pengemudi Gojek. Penelitian ini menemukan bahwa ada pengaruh secara langsung dan signifikan antara employee engagement terhadap knowledge sharing dan kinerja, adanya pengaruh yang signifikan antara knowledge sharing terhadap kinerja. Hasil lainnya juga mengungkapkan bahwa knowledge sharing dapat memediasi pengaruh antara employee engagement terhadap kinerja pengemudi Gojek.

\section{PENDAHULUAN}

Banyak sekali perusahaan baru bermunculan yang mengembangkan aplikasi - aplikasi baru untuk konsumen. Banyak juga perusahaan yang menerapkan aplikasi baru untuk digunakan dalam sistem kantor untuk menunjang kebutuhan operasi pekerjaan sehari - hari. Tuntutan karyawan pada era sekarang ini adalah selalu belajar tentang teknologi yang selalu berkembang, khususnya yang digunakan di perusahaan tempat mereka bekerja. Perkembangan teknologi yang sangat cepat menuntut karyawan selalu belajar menggunakannya. Hadirnya teknologi baru yang seharusnya dapat membantu karyawan dalam pekerjaannya sehari - hari terkadang malah membuat kerja karyawan terganggu bahkan menghilangkan gairah kerja. Kemampuan karyawan dalam menggunakan teknologi yang tepat juga dapat membantu meningkatkan kinerja karyawan.

Proses belajar pengetahuan tentang teknologi baru yang diterapkan tidak selalu berupa pelatihan resmi dari kantor atau perusahaan. Saling berbagi pengetahuan antar karyawan merupakan salah satu cara mudah dalam mengfamiliarkan sebuah teknologi. Membagikan pengetahuan (knowledge 
sharing) antara satu karyawan dengan karyawan yang lain, saling menukarkan informasi, pengalaman, dan pengetahuan diantara karyawan akan dapat meningkatkan kinerja yang berdampak baik bagi perusahaan.

Kinerja adalah hasil kerja secara kualitas dan kuantitas yang dicapai oleh seorang pegawai dalam melaksanakan fungsinya sesuai dengan tanggung jawab yang diberikan kepadanya (Robbins, 2014) Hasibuan (2013) menyatakan bahwa kinerja adalah suatu hasil yang dicapai oleh seseorang dalam melaksanakan tugas-tugas yang dibebankan kepadanya. Untuk mencapai kinerja yang tinggi, baik karyawan maupun organisasi sangat dipengaruhi oleh banyak faktor.

Employee engagement diartikan sebagai keterlibatan, kepuasan, dan antusiasme seseorang untuk bekerja dimana ketika individu berperan dalam pekerjaannya, terikat, dan mengekspresikan diri secara fisik, kognitif, dan emosional dalam menjalankan peran meraka (Kahn, 1990; Albrecht, 2010). Employee engagement juga diartikan sebagai sikap positif seseorang, seperti yang didefinisikan Robinson et al. (2004 dalam Sridevi 2010) bahwa employee engagement sebagai sikap positif terhadap organisasi dan nilainya. Sedangkan menurut Gallup employee engagement merupakan keterli-batan dengan dan antusiasme untuk bekerja (Sridevi, 2010). Gallup juga mengibaratkan employee engagement sebagai ikatan emosional dan komitmen (Sridevi, 2010).

Knowledge sharing sangat diperlukan apalagi pada era perkembangan teknologi yang cepat seperti sekarang ini. Nonaka dan Takeuchi (Aligholi \& Asefikia, 2015) menyatakan knowledge sharing merupakan inti dan dasar dari manajemen pengetahuan. Knowledge sharing adalah proses penting dalam kemajuan organisasi saat ini, karena menyebarkan modal intelektual untuk seluruh organisasi. Knowledge sharing sangat dibutuhkan pada era teknologi informasi seperti sekarang ini. Teknologi yang semakin cepat berkembang membuat manusia, baik sebagai produsen maupun konsumen harus selalu adabtable pada perkembangannya. Kebutuhan masyarakat untuk selalu memiliki mobilitas tinggi sudah menjadi kebutuhan hidup sehari - hari.

Peluang ini ditangkap dengan baik oleh salah satu perusahaan berbasis digital di indonesia. PT Aplikasi Karya Anak Bangsa atau yang lebih dikenal dengan Gojek merupakan sebuah perusahaan teknologi asal Indonesia yang melayani angkutan melalui jasa ojek. Bermula di tahun 2010 sebagai perusahaan transportasi roda dua melalui panggilan telepon, Gojek kini telah tumbuh menjadi on-demand mobile platform dan aplikasi terdepan yang menyediakan berbagai layanan lengkap mulai dari transportasi, logistik, pembayaran, layanantar makanan, dan berbagai layanan on-demand lainnnya.

Gojek telah beroperasi di 50 kota di Indonesia, salah satunya adalah di Yogyakarta. Jumlah pengemudi gojek di Yogyakarta berkisar angara tiga puluh lima ribu lebih, banyak diantaranya yang berasal dari luar daerah Yogyakarta. Setelah melakukan rekrutmen dan proses pendaftaran selesai, maka perusahaan segera menurunkan pengemudi Gojek untuk mulai bekerja. Pengemudi Gojek melaksanakan kerja tanpa adanya pelatihan resmi dari perusahaan. Pengemudi harus belajar sendiri menggunakan aplikasi dengan hanya mengikuti petunjuk buku manual dari perusahaan. Resiko kesalahan dalam penggunaan aplikasi sudah menjadi resiko pengemudi gojek, yang efeknya akan berdampak pada turunnya kinerja yang bisa dilihat langsung dalam sistem aplikasi yang diterapkan. Hal ini dirasa sangat merugikan pengemudi gojek. 
Di lain sisi Gojek selalu berinovasi mengikuti perkembangan dalam teknologi dan selalu dapat menangkap peluang bisnis baru yang dibutuhkan masyarakat. Bermula hanya sebagai angkutan transportasi pada awal berdirinya, sekarang gojek sudah banyak melakukan penambahan bisnis. Layanan awal dari gojek merupakan jenis layanan Go-Ride, yaitu mengantarkan pelanggan dari tempat penjemputan ke tempat tujuan dengan kendaraan motor roda dua. Setelah berjalannya waktu, maka pengemudi gojek memiliki beragam jenis pekerjaan sesuai dengan pengembangan pada layanan konsumen.

Layanan lainnya yaitu seperti Go-Food adalah jenis layanan pesan antar makanan, Go-Send adalah layanan kurir instan untuk kirim barang, dan dokumen dengan cepat tanpa batasan jarak, Go-Mart adalah layanan belanja instan untuk membeli barang dari berbagai macam toko yang telah tersedia di aplikasi, GoShop adalah layanan belanja yang memudahkan pelanggan untuk membeli barang apapun dan di toko manapun dalam 1 area yang sama. Go-Tix merupakan layanan pembelian tiket bioskop maupun tiket pertunjukann lainnya dan sekarang juga ada Go-Med yaitu layanan medis untuk membelikan obat yang sudah dipesan melalui aplikasi. Sistem layanan Go-Med ini bekerja sama dengan aplikasi Halodoc. Selain itu Gojek juga menawarkan layanan lain berupa Go-Pay untuk lebih memudahkan dan membuat nyaman konsumen dalam bertransaksi.

Beberapa kekurangan dalam aplikasi ini sangat dikeluhkan oleh pengemudi Gojek karena berdampak pada menurunnya skor kinerja yang terdapat pada sistem. Pengemudi juga mengeluhkan tentang peraturan selalu berubah, seperti peraturan pemberian bonus, point, dan lain sebagainya. Pemberian bonus juda semakin kecil dengan tuntutan target yang semakin tinggi. Situs berita terpercaya Liputan6.com memberitakan bahwa Ratusan pengemudi Gojek berunjuk rasa menuntut dihapuskannya sistem performa atau rating. Mereka menilai sistem tersebut memberatkan para pengemudi (Oktober, 2016). Pengemudi gojek merasa bahwa jika performa tidak terpenuhi, maka mereka tidak akan mendapatkan bonus, di mana bonus tersebut menjadi faktor penting mendongkrak pendapatan. Banyak syarat yang harus dipenuhi untuk menjaga rating atau performanya yang dianggap memberatkan.

Bahkan parahnya lagi yaitu unsur performa ini akan turun jika ada pesanan dari konsumen yang dibatalkan. Kejadian di lapangan adalah pengemudi sangat sering sekali mendapat order fiktif sehingga mau tidak mau pengemudi harus membatalkan pesanan tersebut. Permasalahannya adalah aplikasi gojek tidak dapat mendeteksi order fiktif tersebut, sehingga berdampak pada skor kinerja yang menurun dan akan berdampak pada bonus uang yang diterima oleh pengemudi gojek.

Untuk melaksanakan layanan lainnya seperti Gofood, Go-Mart, GoShop, Go-Tix, dan Go-Med pengemudi harus mengeluarkan modal terlebih dahulu untuk membelikan barang yang diinginkan konsumen. Terkadang jika pengemudi dapat pesanan fiktif, maka perusahaan tidak bertanggung jawab terhadap uang yang sudah di keluarkan oleh pengemudi. Kejadian ini sangat merugikan pengemudi gojek, karena otomatis pesanan akan dibatalkan yang berdampak pada turunnya skor kinerja pada aplikasi, dan hilangnya uang karena sudah membelikan barang yang diinginkan konsumen.

Banyaknya layanan yang ditawarkan gojek pada konsumen membuat aplikasi ini selalu menambahkan inovasi baru. Akibat inovasi - inovasi yang 
dilakukan ini, aplikasi untuk pengemudi gojek juga sering mendapatkan tambahan menu - menu baru. Biasanya penambahan menu baru yang terdapat pada aplikasi pengemudi gojek, hanya diinformasikan melalui aplikasi dengan nama menu info terkini. Masalah lain juga karena masih disempurnakannya aplikasi gojek, sehingga penggunaannya juga selalu berubah - ubah.

Latar belakang dari pengemudi gojek sangat beragam, seperti latar belakang usia dan tingkat pendidikan. Latar belakang ini sangat mempengaruhi pengemudi untuk menggunakan menu - menu baru yang ada di aplikasi. Peran knowledge sharing sangat tinggi pada kondisi ini, saling komunikasi antar pengemudi Gojek menjadi salah satu kunci untuk mendapatkan informasi informasi guna menaikkan kinerja pengemudi.

\section{Kajian Literature \\ Kinerja}

Pengertian kinerja adalah hasil kerja secara kualitas dan kuantitas yang dicapai oleh seorang pegawai dalam melaksanakan fungsinya sesuai dengan tanggung jawab yang diberikan kepadanya. Menurut pendekatan perilaku dalam manajemen, kinerja adalah kuantitas atau kualitas sesuatu yang dihasilkan atau jasa yang diberikan oleh seseorang yang melakukan pekerjaan, Luthans (2011). Menurut Mangkunegara (2012) kinerja berasal dari kata job performance atau actual performance yang berarti prestasi kerja atau prestasi sesungguhnya yang dicapai oleh seseorang. Mangkunegara (2012) juga menjelaskan bahwa kinerja karyawan (prestasi kerja) adalah hasil kerja secara kualitas dan kuantitas yang dicapai oleh seseorang karyawan dalam melakasanakan tugasnya sesuai dengan tanggung jawab yang diberikan kepadanya. Supriyanto (2010) dalam mencapai tujuan yang telah ditetapkan organisasi dapat melakukan usaha-usaha dari sumbernya yang berkualitas. Usaha ini dapat berupa pengembangan, perbaikan sistem kerja, sebagai kelanjutan penilaian terhadap prestasi kerja karyawan yang telah dicapainya dengan kemampuan yang telah dimilikinya pada kondisi tertentu. Dengan demikian kinerja merupakan hasil keterkaitan antara usaha, kemampuan, dan persepsi tugas yang telah dibebankan.

Menurut Gibson, dkk (2012), job performance adalah hasil dari pekerjaan yang terkait dengan tujuan organisasi, efisiensi dan kinerja kefektifan kinerja lainnya. Kinerja merupakan gabungan tiga faktor penting, yaitu kemampuan dan minat seorang pekerja, kemampuan dan penerimaan atas penjelasan delegasi tugas dan peran serta tingkat motivasi pekerja (Hasibuan, 2013). Indikator untuk mengukur kinerja karyawan secara individu ada enam indikator, yaitu (Robbins, 2014):

1. Kualitas. Kualitas kerja diukur dari persepsi karyawan terhadap kualitas pekerjaan yang dihasilkan serta kesempurnaan tugas terhadap keterampilan dan kemampuan karyawan.

2. Kuantitas. Merupakan jumlah yang dihasilkan dinyatakan dalam istilah seperti jumlah unit, jumlah siklus aktivitas yang diselesaikan.

3. Ketepatan waktu. Merupakan tingkat aktivitas diselesaikan pada awal waktu yang dinyatakan, dilihat dari sudut koordinasi dengan hasil output serta memaksimalkan waktu yang tersedia untuk aktivitas lain. 
4. Efektivitas. Merupakan tingkat penggunaan sumber daya organisasi (tenaga, uang, teknologi, bahan baku) dimaksimalkan dengan maksud menaikkan hasil dari setiap unit dalam penggunaan sumber daya.

5. Kemandirian. Merupakan tingkat seorang karyawan yang nantinya akan dapat menjalankan fungsi kerjanya Komitmen kerja. Merupakan suatu tingkat dimana karyawan mempunyai komitmen kerja dengan instansi dan tanggung jawab karyawan terhadap kantor.

\section{Knowledge sharing}

Menurut Hoof (Ologbo, 2015), knowledge sharing adalah proses timbal balik dimana individu saling bertukar pengetahuan (tacit dan explicit knowledge) dan secara bersama- sama menciptakan pengetahuan (solusi) baru. Salah satu tujuan definisi ini terdiri dari memberikan dan mengumpulkan knowledge, dimana memberikan knowledge dengan cara mengkomunikasikan pengetahuan kepada orang lain apa yang dimiliki dari personal intellectual capital seseorang, dan mengumpulkan pengetahuan merujuk pada berkonsultasi dengan rekan kerja dengan membagi informasi atau intellectual capital yang mereka miliki.

Hooff and Weenen (dalam Obeidat 2017) mengiden-tifikasi dua dimensi proses knowledge sharing. Pertama adalah mentransfer pengetahuan, yang berarti bertukar dan berkomunikasi dengan orang lain, modal intelektual dari pribadi seseorang. Dimensi kedua adalah mengumpulkan pengetahuan yang mengacu pada konsultasi rekan untuk mendorong mereka untuk berbagi modal intelektual mereka

Menurut Hoof dan Ridder (Yesil, 2013), knowledge sharing adalah proses timbal balik dimana individu saling bertukar pengetahuan (tacit dan explicit knowledge) dan secara bersama-sama menciptakan pengetahuan (solusi) baru. Proses dalam knowledge sharing ini terdiri dari dua dimensi yaitu Memberikan pengetahuan (knowledge donating) dan Mengumpulkan pengetahuan (knowledge collecting). Memberikan pengetahuan (knowledge donating) adalah menyalurkan / menyebarkan pengetahuan atau modal inteletual kepada orang lain yang melibatkan komunikasi antar individu. Mengumpulkan pengetahuan (knowledge collecting) adalah mencari / mengumpulkan pengetahuan atau modal intelektual dengan jalan berkonsultasi dengan orang lain.

\section{Employee engagement}

Saks (2006 dalam Schaufeli 2017) employee engagement dapat diartikan sebagai suatu konstruksi yang terdiri dari kognitif, emosional, dan perilaku yang berkaitan dengan peran individu dalam bekerja. Menurut Robbins dan Judge (2014) employee engagement di definisikan sebagai kondisi dimana karyawan memiliki gairah untuk pekerjaan mereka dan merasakan hubungan yang mendalam untuk organisasi mereka, sedangkan karyawan yang tidak memiliki keterikatan atau engagement, pada dasarnya telah menempatkan waktu untuk bekerja tetapi tidak memiliki energi atau perhatian ke dalam pekerjaan mereka.

Schaufeli (2017) menyatakan bahwa engagement dikarakteristikan dengan 3 hal yakni vigor, dedication dan absorption. Vigor dapat dicirikan dengan memiliki energi dan kegigihan yang tinggi yang disertai dengan kegembiraan, kerelaan dalam mengeluarkan usaha yang maksimal dalam 
menyelesaikan pekerjaan yang ditandai dengan ketekunan dalam menghadapi kesulitan. Dedication merupakan suatu kondisi dimana pekerja sangat terlibat dengan pekerjaannya. Kondisi tersebut ditandai dengan adanya perasaan yang penuh makna, tertantang, antusiasme yang tinggi dan memberikan inspirasi yang signifikan bagi dirinya baik secara pribadi maupun sosial. Absorption dapat didefinisikan sebagai suatu tahapan yang ditandai dengan adanya konsentrasi dan kesenangan hati serta minat yang mendalam pada pekerjaan. Hal tersebut dicirikan dengan perasaan sulit melepaskan diri dari pekerjaan dan merasa waktu sangat cepat berlalu ketika melakukan pekerjaan tersebut.

\section{Hubungan antar variabel}

Hasil penelitian dari Kim dan Jiwon Park (2017) menyatakan bahwa employee engagement mempunyai pengaruh positif dan signifikan terhadap knowledge sharing. Penelitian Matzler et. al., (2008) menyatakan bahwa berbagi pengetahuan sangat penting bagi individu didalam suatu organisasi untuk dapat mengembangkan keahlian dan kompetensi, meningkatkan nilai bagi organisasi, dan dapat menjaga daya saing sebab inovasi didapatkan berasal dari berbagi pengetahuan antara orang personal di dalam organisasi. Penelitian Sridevi (2010) menemukan yang hubungan positif antara employee engagement dan kinerja organisasi seperti retensi karyawan, produktivitas, profitabilitas, loyalitas pelanggan dan keamanan. Penelitian juga menunjukkan bahwa semakin tinggi employee engagement, maka semakin besar juga kemungkinan perusahaan mereka untuk melebihi rata-rata industri dalam pertumbuhan pendapatannya.

Mathew (2010) berpendapat bahwa keberadaan pengetahuan dan pengembangan budaya knowledge sharing dalam lingkungan organisasi akan menghasilkan inovasi dan meningkatkan kinerja. Keterlibatan dapat mengarah pada perhatian penuh, motivasi intrinsik, kreativitas, keaslian, komunikasi nondefensif, perilaku etis. Meningkatnya usaha dan kese-luruhan karyawan yang lebih produktif dan bahagia (Kahn dalam Bedarkar, 2014 ).

\section{Pengembangan Hipotesis}

1.Ada pengaruh yang signifikan antara variabel Employee engagement terhadap variabel knowledge sharing pengemudi Go-jek di Yogyakarta.

2.Ada pengaruh yang signifikan antara variabel knowledge sharing karyawan terhadap kinerja pengemudi Go-jek di Yogyakarta.

3. Ada pengaruh yang signifikan antara variabel Employee engagement terhadap variabel kinerja pengemudi Go-jek di Yogyakarta.

4. Ada pengaruh tidak langsung antara variabel Employee engagement terhadap variabel kinerja yang dimediasi oleh knowledge sharing.

\section{Metode Penelitian}

Penelitian ini menggunakan metode penelitian survei dan termasuk penelitian penjelasan (explanatory research) dengan pendekatan penelitian kuantitatif. Data primer diperoleh dengan menyebarkan angket yang ditujukan dan diisi oleh pengemudi Go-Jek yang menjadi sampel. Populasi dari penelitian ini adalah seluruh pengemudi Go-Jek yang berada di Yogyakarta. Teknik pengambilan sampel menggunakan purposive cluster sampling, dengan jumlah sampel sebanyak 200 pengemudi Go-Jek. Kriteria sampel dalam penelitian ini 
adalah pengemudi Go-Jek yang sudah aktif lebih dari tiga bulan atau lebih dan beroperasi di Yogyakarta.

Variabel dalam penelitian ini terdiri dari variabel Employee engagement yang merupakan variabel bebas atau eksogen, variabel knowledge sharing yang merupakan variabel intervening atau endogen dan variabel kinerja yang merupakan variabel terikat atau endogen.

Pengukuran variabel kinerja dikembangkan dari teori Robbins (2014). Teori ini kemudian disesuaikan dengan sistem penilaian kinerja melalui aplikasi yang sudah diterapkan pada Gojek. Variabel kinerja ini menggunakan item skor Performa, keberhasilan memperoleh points, keberhasilan memperoleh bonus uang, sistem pemberian bintang oleh konsumen, tingkat komplain konsumen, tingkat komplain perusahaan, tingkat kepatuhan dalam berlalu - lintas dan sanksi yang diberikan oleh perusahaan.

Variabel knowledge sharing diukur menggunakan skala yang dikembangkan oleh De Vries and Van den Hooff dalam Ologbo (2015). Skala ini yang menggunakan dua dimensi, yaitu sumbangan pengetahuan dan pengumpulan pengetahuan dengan masing - masing dimensi memiliki 4 item pertanyaan.

Pengukuran variabel Employee engagement menggunakan skala Work Engagement Scale (UWES) yang dikembang-kan oleh Schaufeli dan Shimazu (2017). Skala ini menggunakan tiga dimensi yaitu vigor, dedication dan absorption. Skala ini menggunakan 17 item pertanyaan yang diadopsi dari penelitian Titien (2016) dan Schaufeli dan Shimazu (2017), yang kemudian disesuaikan dengan objek peneltian.

Alat analisis yang digunakan dalam penelitian ini adalah analisis jalur atau path analysis. Sebelum melakukan uji hipotesis maka digunakan uji prasyarat dengan melakukan uji validitas dan uji reliabilitas terlebih dahulu.

\section{Hasil Penelitian}

Analisis kuantitatif ditujukan untuk menguji hipotesis ada tidaknya pengaruh Employee engagement terhadap Kinerja karyawan melalui Knowledge sharing sebagai variabel intervening pada pengemudi Gojek di Yogyakarta. Pengujian dilakukan dengan path analysis menggunakan SPSS 23

\section{Estimasi Path Analysis}

\section{a. Model Regresi $\mathrm{I}\left(\mathrm{Z}=\boldsymbol{p}_{1} \mathrm{X}+\mathbf{e}_{1}\right)$}

Estimasi terhadap model regresi I dilakukan untuk mengetahui ada tidaknya pengaruh variabel independen Employee engagement (X) terhadap variabel intervening Knowledge sharing (Z).

Tabel 1

Hasil Model Regresi I $\left(Z=p_{1} X+e_{1}\right)$

\begin{tabular}{|l|c|c|c|c|}
\hline \multicolumn{1}{|c|}{$\begin{array}{c}\text { Variabel } \\
\text { Eksogen }\end{array}$} & $\begin{array}{c}\text { Koef. } \\
\text { Path }\end{array}$ & $\mathbf{t}_{\text {hitung }}$ & Sig.t & Ket. \\
\hline Employee engagement $(\mathrm{X})$ & 0,510 & 6,751 & 0,000 & Signifikan \\
\hline Variabel dependen: Knowledge sharing (Z) \\
$\mathrm{R}_{\mathrm{Z} \quad=0,260}$ \\
$\mathrm{~F}_{\text {hitung }=45,580}$ \\
Sig.F $=0,000$ \\
\hline
\end{tabular}

Sumber: Data primer yang diolah tahun 2018 
Dari Tabel 1 diperoleh koefisien path pengaruh langsung Employee engagement terhadap Knowledge sharing $\left(p_{1}\right)$ sebesar 0,510 (positif) dan

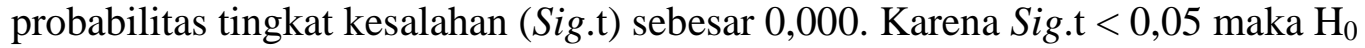
ditolak pada taraf signifikansi 0,05 , yang berarti ada pengaruh secara langsung yang positif dan signifikan Employee engagement terhadap Knowledge sharing.

Ditemukan pula koefisien determinasi $\left(\mathrm{R}^{2} \mathrm{z}\right)$ sebesar 0,260 yang berarti sekitar 26\% perubahan-perubahan atau variasi pada variabel Knowledge sharing yang mampu dijelaskan (explained) oleh variabel Employee engagement. Error term $\left(\mathrm{e}_{1}\right)$ atau variasi yang tidak mampu dijelaskan (unexplained) diperoleh sebesar $\left(1-\mathrm{R}_{\mathrm{Z}}^{2}\right)=(1-0,260)$ atau sebesar 0,260 . Jadi sekitar $74 \%$ variasi pada variabel Knowledge sharing yang tidak mampu dijelaskan oleh variabel Employee engagement.

\section{b. Model Regresi II ( $\left.\mathrm{Y}=p_{2} \mathrm{Z}+\boldsymbol{p}_{3} \mathrm{X}+\mathbf{e}_{2}\right)$}

Estimasi terhadap model regresi II dilakukan untuk mengetahui ada tidaknya pengaruh Employee engagement (X) terhadap Kinerja (Y) yang dimediasi oleh Knowledge sharing (Z).

\section{Tabel 2}

Hasil Model Regresi II ( $\left.\mathrm{Y}=p_{2} \mathrm{Z}+p_{3} \mathrm{X}+\mathrm{e}_{2}\right)$

\begin{tabular}{|c|c|c|c|c|}
\hline $\begin{array}{l}\text { Variabel } \\
\text { Eksogen/ } \\
\text { Endogen }\end{array}$ & $\begin{array}{l}\text { Koef. } \\
\text { Path }\end{array}$ & $\mathbf{t}_{\text {hitung }}$ & Sig.t & Ket. \\
\hline Knowledge sharing $(\mathrm{Z})$ & \multirow{2}{*}{$\begin{array}{l}0,471 \\
0,230\end{array}$} & 5,868 & 0,000 & Signifikan \\
\hline $\begin{array}{l}\text { Employee engagement } \\
(\mathrm{X})\end{array}$ & & 2,864 & 0,005 & Signifikan \\
\hline \multicolumn{5}{|c|}{ Variabel dependen: Kineria (Y) } \\
\hline \multicolumn{5}{|c|}{$=0,385$} \\
\hline \multicolumn{5}{|l|}{$=40,360$} \\
\hline \multicolumn{5}{|l|}{$=0,000$} \\
\hline
\end{tabular}

Sumber: Data primer yang diolah tahun 2018

Dari Tabel 2 diperoleh koefisien path pengaruh langsung Knowledge sharing terhadap Kinerja $\left(p_{2}\right)$ sebesar 0,471 (positif) dan probabilitas tingkat kesalahan (Sig.t) sebesar 0,000. Karena Sig.t $<0,05$ maka $\mathrm{H}_{0}$ ditolak pada taraf signifikansi 0,05 , yang berarti ada pengaruh secara langsung yang positif dan signifikan Knowledge sharing terhadap Kinerja.

Koefisien path pengaruh langsung Employee engagement terhadap Kinerja $\left(p_{3}\right)$ sebesar 0,230 (positif) dan probabilitas tingkat kesalahan (Sig.t) sebesar 0,000. Karena Sig.t $<0,05$ maka $\mathrm{H}_{0}$ ditolak pada taraf signifikansi 0,05, yang berarti ada pengaruh secara langsung positif dan signifikan Employee engagement terhadap Kinerja.

Koefisien determinasi $\left(\mathrm{R}^{2} \mathrm{Y}\right)$ sebesar 0,385 yang berarti sekitar 38,5\% perubahan-perubahan atau variasi pada variabel Kinerja yang mampu dijelaskan (explained) oleh kedua variabel Knowledge sharing dan Employee engagement. Error term $\left(\mathrm{e}_{2}\right)$ atau variasi yang tidak mampu dijelaskan (unexplained) diperoleh sebesar $\left(1-\mathrm{R}_{\mathrm{Y}}^{2}\right)=(1-0,385)$ atau sebesar 0,615 . Jadi sekitar $61,5 \%$ 
variasi pada variabel Kinerja yang tidak mampu dijelaskan oleh kedua variabel Knowledge sharing dan Employee engagement.

Keseluruhan hasil estimasi model hubungan hipotesis antar ketiga variabel dalam penelitian ini disajikan dalam bentuk diagram path pada Gambar 1 .

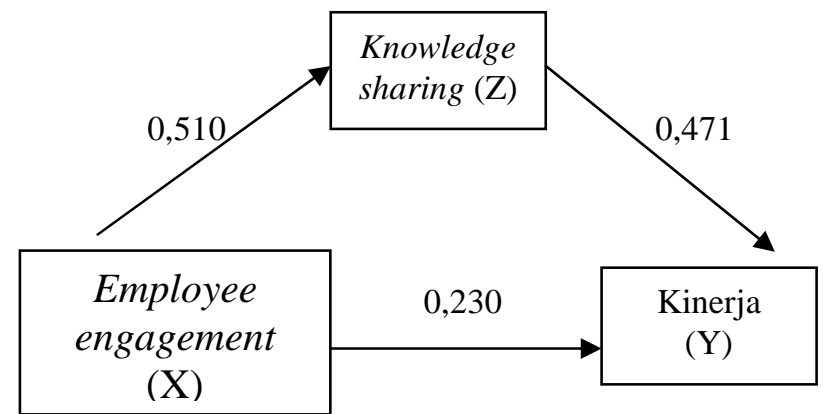

Gambar 1

Hasil Estimasi Koefisien Path

Hubungan Antar Variabel

Hasil estimasi model di atas dapat dinyatakan dalam dua bentuk persamaan path sebagai berikut:

1. $\mathrm{Z}=0,510 \mathrm{X}+0,740 ; \quad \mathrm{R}^{2}=0,260$

2. $\mathrm{Y}=0,471 \mathrm{Z}+0,230 \mathrm{X}+0,615 ; \quad \mathrm{R}^{2}=0,385$

Hasil perhitungan pengaruh langsung (direct effect), tak langsung (indirect effect) dan pengaruh total (total effect) Employee engagement terhadap Kinerja karyawan, disajikan pada Tabel 3

Tabel 3

Tabel Koefisien Direct Effect, Indirect Effect dan Total Effect

\begin{tabular}{|c|c|}
\hline \multicolumn{2}{|l|}{ Direct effect } \\
\hline$X \rightarrow Y$ & \\
\hline$\left(p_{3}\right)$ & $=0,230$ \\
\hline Indirect effect: & \\
\hline$X \rightarrow Z \rightarrow Y$ & \\
\hline$\left(p_{1} \times p_{2}=0,510 \times 0,471\right)$ & $=0,240$ \\
\hline Total Effect & \\
\hline $\begin{array}{l}\text { (Direct Effect }+ \text { Indirect Effect } \\
=0,230+0,240)\end{array}$ & $=0,470$ \\
\hline
\end{tabular}

Berdasarkan Tabel 3 dapat dilihat bahwa Employee engagement mempunyai pengaruh secara tak langsung (indirect effect) terhadap Kinerja melalui Knowledge sharing sebesar 0,187. Pengaruh secara langsung diperoleh sebesar 0,230 sehingga total pengaruh (total effect) Employee engagement terhadap Kinerja adalah sebesar $0,230+0,240=\mathbf{0 , 4 7 0}$.

Pengujian signifikansi pengaruh tak langsung (indirect effect) employee engagement terhadap Kinerja yang dimediasi oleh Knowledge sharing dengan statistik Z ( $Z_{\text {hitung }}$ ) dapat dihitung dengan formula Sobel Test. Didapatkan nilai $Z_{\text {hitung }}=2.63798193>1,96$ dan nilai signifikansi $0,0083401<0,050$ yang berarti 
signifikan pada taraf signifikansi 0,05. Jadi dapat simpulkan bahwa Employee engagement secara signifikan mempunyai pengaruh tak langsung terhadap Kinerja melalui Knowledge sharing.

\section{Pembahasan}

Hasil penelitian ini menunjukkan bahwa secara langsung terdapat pengaruh signifikan Employee engagement terhadap variabel knowledge sharing pengemudi Go-jek di Yogyakarta. Hasil penelitian dari Kim dan Jiwon Park (2017) menyatakan bahwa employee engagement mempunyai pengaruh positif dan signifikan terhadap knowledge sharing. Penelitian Matzler et. al., (2008) menyatakan bahwa berbagi pengetahuan sangat penting bagi individu didalam suatu organisasiuntuk dapat mengembangkan keahlian dan kompetensi, meningkatkan nilai bagi organisasi, dan dapat menjaga daya saing sebab inovasi didapatkan berasal dari berbagi pengetahuan antara orang personal di dalam organisasi.

Hasil penelitian ini menunjukkan bahwa Employee engagement pengemudi masih tergolong belum terlalu kuat. Hal ini terlihat pada pengemudi yang belum terlalu gigih dalam menyelesaikan tantangan -tantangan yang ada dilapangan. Pengemudi kadang enggan untuk menerima pesanan dari konsumen dengan jarak tempuh yang jauh. Pengemudi terkadang juga enggan menerima pesanan Gofood dengan jenis pesanan dengan variasi yang banyak. Perasaan saling terhubung dengan persaan mendalam belum dapat diciptakan oleh perusahaan pada pengemudi Gojek. Perusahaan belum dapat menciptakan pengemudi yang dapat menunjukkan perasaan terahadap peker-jaannya yang selalu penuh makna, tertantang dan selalu memberikan antusiasme pada pekerjaannya.

Penelitian ini juga mengungkapkan bahwa Ada pengaruh yang signifikan antara variabel knowledge sharing karyawan terhadap kinerja pengemudi Go-jek di Yogyakarta. Hasil ini mendukung Mathew (2010) yang berpendapat bahwa keberadaan pengetahuan dan pengembangan budaya knowledge sharing dalam lingkungan organisasi akan menghasilkan inovasi dan meningkatkan kinerja. Hasil ini juga mendukung pendapat Kahn (Bedarkar, 2014) yang menyatakan bahwa keterlibatan dapat mengarah pada perhatian penuh, motivasi intrinsik, kreativitas, keaslian, komunikasi non-defensif, perilaku etis. Meningkatnya usaha dan keseluruhan karyawan yang lebih produktif dan bahagia.

Hasil deskripsi variabel terlihat bahwa knowledge sharing pada pengemudi Gojek masih belum baik. Pengemudi masih jarang bisa berkomunikasi secara intensif dengan rekannya terkait dengan perubahan - perubahaan yang ada di sistem perusahaan Gojek. Beberapa pengemudi bahkan belum menyadari jika berbagi pengetahuan dan informasi tentang pekerjaan akan meningkatkan kinerja mereka juga. Pengemudi yang memiliki sifat kurang komunikatif juga akan merasa canggung untuk berinteraksi dengan rekan pengemudi lainnya dan jarang bergabung dengan komunitas pengemudi Gojek. Interaksi tanya jawab terkait tentang pekerjaan juga dirasa kurang maksimal. Hanya pengemudi yang memiliki komunitas yang dapat melakukan interakasi dengan grup sosial media seperti grup Facebook maupun grup aplikasi Whatsapp. Pengemudi yang tidak bergabung dengan komunitas Gojek, biasanya sangat lamban menerima informasi informasi terkini tentang perkembangan sistem pekerjaan. 
Hasil lain dari penelitian juga mendapatkan bahwa ada pengaruh yang signifikan antara variabel employee engagement terhadap variabel kinerja pengemudi Go-jek di Yogyakarta. Hasil ini mendukung penelitian Sridevi (2010) yang menemukan bahwa hubungan positif antara employee engagement dan kinerja organisasi seperti retensi karyawan, produktivitas, profitabilitas, loyalitas pelanggan dan keamanan. Penelitian Sridevi (2010) juga menunjukkan bahwa semakin tinggi employee engagement, maka semakin besar juga kemungkinan perusahaan mereka untuk melebihi rata-rata industri dalam pertumbuhan pendapatannya.

Kurang kuatnya employee engagement terlihat dampaknya pada kinerja pengemudi Gojek yang masih kurang maksimal. Pengemudi masih banyak yang tiap harinya belum memperoleh point yang tinggi tapi sudah memilih untuk mengakhiri hari kerjanya. Pengemudi juga sering mendapatkan skor performa yang menurun akibat pesanan dari pelanggan yang mereka batalkan. Beberapa pengemudi juga tak jarang mendapatkan keluhan dari pelanggan langsung karena keramahannya dan kurangnya mengerti tentang pesanan makanan dari konsumen. Beberapa pengemudi juga mengakui bahwa terkadang kurang patuh dalam berlalu - lintas karena mengejar target yang ditetapkan perusahaan.

Penelitian ini juga menemukan bahwa ada pengaruh tidak langsung antara variabel employee engagement terhadap variabel kinerja yang dimediasi oleh knowledge sharing pada pengemudi Go-jek. Hasil penelitian ini sesuai dengan penelitian yang dilakukan oleh Akram and Bokhari (2011) yang menemukan bahwa knowledge sharing memiliki hubungan yang positif terhadap kinerja individual karyawan. Penelitian lain yang didukung adalah penelitian Hakan (2013) yang memiliki kesamaan hasil yaitu knowledge sharing mempunyai pengaruh kuat terhadap kinerja karyawan.

Employee engagement yang kuat akan dapat membentuk tingkat knowledge sharing yang tinggi dan akan berdampak pada kinerja pengemudi Go-jek yang lebih maksimal. Jika karyawan tidak memiliki employee engagement yang kuat, maka dikhawatirkan akan muncul perilaku karyawan yang enggan untuk melakukan perubahan dalam organisasi, karyawan yang bekerja tidak efektif dan efisien, atau bahkan karyawan selalu merasa khawatir terhadap segala bentuk evaluasi kinerja. Sebenarnya jika perusahaan dapat membentuk employee engagement yang kuat maka karyawan akan merasa tidak enggan untuk berkomunikasi apalagi berbagi pengetahuan dan informasi pada rekan kerjanya, sehingga memiliki knowledge sharing yang tinggi karena dalam penelitian ini terbukti bahwa knowledge sharing dapat memdiasi pengaruh employee engagement terhadap kinerja pengemudi Go-jek.

\section{Kesimpulan}

1. Ada pengaruh yang signifikan antara variabel Employee engagement terhadap variable knowledge sharing pengemudi Go-jek di Yogyakarta. Hal ini berarti bahwa jika employee engagement semakin baik, maka Knowledge sharing karyawan akan meningkat, bagitu juga sebaliknya jika employee engagement buruk maka akan mengurangi Knowledge sharing.

2. Ada pengaruh yang signifikan antara variabel knowledge sharing karyawan terhadap kinerja pengemudi Go-jek di Yogyakarta. Jika Knowledge sharing meningkat maka Kinerja karyawan akan semakin baik, begitu juga 
sebaliknya jika Knowledge sharing karyawan menurun maka akan berpengaruh juga pada Kinerja karyawa yang rendah .

3. Ada pengaruh yang signifikan antara variabel Employee engagement terhadap variabel kinerja pengemudi Go-jek di Yogyakarta. Hal ini berarti bahwa jika Employee engagement meningkat maka Kinerja karyawan akan semakin baik, begitu juga sebaliknya jika Employee engagement menurun maka akan berpengaruh juga pada Kinerja karyawa yang rendah.

4. Ada pengaruh tidak langsung antara variabel Employee engagement terhadap variabel kinerja yang dimediasi oleh knowledge sharing.

\section{Saran}

Terkait hasil temuan penelitian maka peneliti menyarankan pada perusahaan untuk memperbaiki fasilitas karyawan yang langsung terkait dengan kinerja seperti perbaikan aplikasi yang ramah dengan pengemudi gojek, sehingga dapat mening-katkan kinerja. Perusahaan juga dapat menambah jumlah operator sehingga pengemudi yang akan menghubungi tidak terlalu lama menunggu antri berbicara dengan operator. Perusahaan juga bisa memberikan fasilitas bebas pulsa bagi pengemudi yang ingin menghubungi operator, baik lewat telepon maupun melalui panggilan mengguna-kan internet. Lamanya antrian dan mahalnya biaya telepon akan menyebabkan pengemudi merasa malas untuk menyampaikan keluhannya yang akan berdampak pada menurunnya skor kinerja pada aplikasi.

Perusahaan bisa juga lebih memperhatikan komunitas yang sudah terbentuk sebagai sarana pengemudi Gojek untuk salin bertukar informasi dan mengcari informasi terkini. Perusahaan dapat mengkoordinasi dengan pengurus komunitas - komunitas terserbut. Saran lain untuk pengemudi gojek, agar selalu dapat melakukan knowledge sharing maka disarankan untuk bergabung dengan komunitas yang sudah ada ataupun dapat membuat komunitas diskusi sendiri.

Untuk penelitian yang akan datang diharapkan, untuk dapat memperluas model penelitian ini dan menambahkan beberapa variabel lain yang dapat mempengaruhi kinerja pengemudi Gojek. Diharapkan juga dapat memperluas jumlah sampel dan daerah penelitian karena jumlah responden atau sampel yang ada masih relatif kecil, dapat juga penelitian dilakukan di perusahaan yang bergerak dalam bidang lain.

\section{Daftar Pustaka}

Akram, F dan Bokhari, R. 2011. The Role of Knowledge Sharing on Individual Performance, Considering the Factor of Motivation -The Conceptual Framework. International Journal of Multidiciplinary Sciences. vol.3, no. 2 , pp. $44-48$

Albrecht, S. (2010). Handbook of employee engagement. Cheltenham, England: Edward Elgar

Aligholi. M., \& Asefikia. M., (2015).The Relationship between knowledge Sharing and innovation and their impact on market development. Applied mathematics in Engineering, Management and Technology Vol. 3 No. 2, pp. 1-9

Bedarkar, Madhura and Deepika Pandita. 2014. "A Study on the Drivers of Employee Engagement Impacting Employee Performance." Procedia - 
Social and Behavioral Sciences 133:106-15. Retrieved (http://dx.doi.org/10.1016/j.sbspro.2014.04.174

Gibson, James L., Donnelly Jr, James H., Ivancevich, John M., Konopaske, Robert (2012). Organizationa Behavior, Structure, Processes, Fourteenth Edition (International Edition).1221 Avenue of The Americas,

Gojek.com, 2017, Layanan Gojek https://www.gojek.com/?gclid=EAIaIQobChMIuayJwsHX2QIVFIWPCh1PYwMxEAA YASAAEgLnXfD_BwE, diakses tanggal 2 Desember 2017

Hakan, Ömür, Kuzu, and Özilhan, Derya, The Effect of Employee Relationships and Knowledge Sharing on Employees' Performance: An Empirical Research on Service Industry, 2nd World Conference On Business, Economics And Management- WCBEM 2013

Hasibuan, S.P,Malayu. 2013. Manajemen Sumber Daya Manusia. Jakarta: PT Bumi Aksara

Kim, W., \& Park, J. (2017). Examining structural relationships between work engagement, organizational procedural justice, knowledge sharing, and innovative work behavior for sustainable organizations. Sustainability, 9 (2), 1-16

Liputan 6.com , Pramono, FX. Richo, Curhat Driver Gojek soal Bonus Tak Cair Gara-Gara Sistem Rating, 03 Okt 2016, 10:02 WIB http://news.liputan6.com/read/2616462/curhat-driver-gojek-soal-bonustak-cair-gara-gara-sistem-rating, Diakses tanggal 14 Maret 2017

Luthans, Fred. 2011. Organizational Behavior: An Evidence-Based Approach New York: McGraw-Hill

Mangkunegara, A.A Anwar Prabu (2012). Manajemen Sumber Daya Manusia. Bandung: PT. Remaja Rosdakarya.

Mathew, V. 2010. "Service Delivery Through Knowledge Management In Higher Education". Journal of Knowledge Management Practice, 11(3): 1-15

Matzler, K., Renzl, B., Julia M, Herting, S., Mooradian, T.A., 2008, "Personality Traits and Knowledge Sharing", Journal of Economic Psychology Vol. 29 pp.301-313

Ologbo , Andrew C., Nor, Khalil Md, Eugene Okyere-Kwakye, The Influence of Knowledge Sharing on Employee Innovation Capabilities, International Journal of Human Resource Studies, ISSN 2162-3058, 2015, Vol. 5, No. 3

Robbins, P. Stephen dan Judge, Timothy 2014, Perilaku Organisasi. Terjemahan., Salemba Empat, Jakarta.

Schaufeli, W. B., Shimazu, A., Hakanen, J., Salanova, M., \& De Witte, H. (2017, October 17). An Ultra-Short Measure for Work Engagement: The UWES-3 Validation Across Five Countries. European Journal of Psychological Assessment. Advance online publication.

Sridevi, M. Sandhya Employee Engagement: The Key to Improving Performance, International Journal of Business and Management Vol. 5, No. 12; December 2010

Supriyanto, Ahmad Sani, dan Masyhuri Machfudz. (2010). Metodologi Riset Manajemen Sumber Daya Manusia. Malang: UIN Maliki Press 
Tintien, 2016, Penyusunan dan Pengembangan Alat Ukur Employee Engagement. Jurnal Psikologi Vol. 1 No. 1, November 2016, 113130. Yogyakarta: Universitas Gadjah Mada

Yesil, S., Dereli, S.F. (2013). An empirical investigation of the organizational justice, knowledge sharing and innovation capability. Social and Behavioural Sciences, 75, 199-208 